\title{
The Effect of Financing and Non-Financing Income on Islamic Banks' Risk: Evidence from Gulf Cooperation Council Countries
}

\author{
Submitted 20/1 1/19, 1st revision 19/12/19, 2nd revision 23/01/20, accepted 14/02/20
}

\author{
Demeh Daradkah ${ }^{1}$, Montaser Al-Sayyah ${ }^{2}$
}

\begin{abstract}
:
Purpose: This study investigates the effect of income structure on Islamic banks' risk in Gulf Cooperation Council (GCC) countries. The main objective was to investigate whether a great reliance on non-financing income, and different types of non-financing income (Fees and Commission, Trading Income, and Other Income) impacts the riskiness of Islamic banks. Design/Methodology/Approach: A panel dataset of 16 Islamic banks from Bahrain, Saudi Arabia, Qatar, United Arab Emirates, and Kuwait during the period 2010 to 2016 were used to achieve the objectives of this study.

Findings: The study found evidence that Islamic banks' risks are decreased and stability is improved by non-financing income. In addition, the study found that components of nonfinancing income have different impacts on Islamic banks' risk, where trading income and other income have decreased the Islamic banks' risk. Islamic banks are found to be more focused on financing activities than non-financing activities (innovative activities).

Practical Implications: These findings have important practical implications to Islamic banks in order to deal with non-financing income to boost their growth worldwide. Moreover, these findings have important implications for Islamic banks' management.

Originality/value: Testing the effect of income structure in the banking industry is still relatively needed. Furthermore, the Islamic banks literature has been largely ignored.
\end{abstract}

Keywords: Non-financing income, Islamic Banks, trading income, other income, GCC.

JEL Codes: G20.

Paper type: Research Article.

\footnotetext{
${ }^{1}$ Corresponding author, Associate Professor, Department of Finance and Banking Science, Faculty of Economics and Administrative Sciences, Yarmouk University, E-mail: d_daradkah@yu.edu.jo

${ }^{2}$ Based on his Master's thesis substantially revised and expanded with new contributions. Department of Finance and Banking Science, Faculty of Economics and Administrative Sciences, Yarmouk University, E-mail: montaseralsayyah@yahoo.com
} 


\section{Introduction}

Islamic banks are financial institutions that undertake financial operations under the basis of Islamic law (sharia' law), that prohibit the use of interest (Roy, 1991).

'Islamic banks' income consists of financing and non-financing income. Financing income consists of Profit Loss Sharing (PLS), in which it derived from Mudaraba (profit-sharing) and Musharaka (joint venture). Non-Profit Loss Sharing (Non-PLS), in which is derived from Murabaha (cost plus), Ijarah (leasing), Bai' muajjal (deferred payment sale), Bai'Salam (forward sale), and Istisna (contract manufacturing)"(Grassa, 2012).

On the other hand, non-financing income is derived from fees and commission income, trading income, and other sources of income such as investments held by banks (Molyneux and Yip, 2013). Recently, the structure of banks' income changed rapidly, where interest income (called financing income in Islamic bank) growing faster than non-interest income (called non-financing income in Islamic bank). Thus, the great financial crisis 2007-2009, results in a decline in interest income (Rose and Hudgin, 2013). Moreover, banks' managers tend to develop and create new fee income services, to improve their profitability and reduce their risk.

Islamic banks have been successful in achieving rapid economic growth, were total assets increased from $\$ 490$ billion in 2010 to $\$ 882$ billion at the end of 2014 , where Gulf Cooperation Council (GCC) countries are the major players, representing $68.71 \%$ of total Islamic assets, in which Saudi Arabia contributes 33\% of global Islamic banking assets, followed by, United Arab Emiratis contributes 15.4\% of global Islamic banking assets. Kuwait and Qatar contributes $10.1 \%$ and $8.1 \%$, respectively of global Islamic banking assets. Finally, Bahrain contributes $1.6 \%$ of global Islamic banking assets (EY, 2016).

In order for the Islamic banks to survive in the competitive banking industry, Islamic banks started to diversify their income to non-financing sources and increase the share of non-financing income. Given the importance of the Islamic banking industry and the contribution of GCC countries, one may be surprised that Islamic banks have been largely ignored in existing literature review, besides of few studies (Grassa, 2012; Molyneux and Yip, 2013; Siti, 2018) and studies concerning income structure and its possible impact on bank risk in GCC countries. Therefore, the objective of this study is to highlight the evidence available in GCC with regard to this issue, during the period from 2010 to 2016.

\section{Literature Review}

Over the last two decades, the income structure and the combination between interest income (traditional activities), and non-interest income (innovative activities) in banking industry have given serious attention by bankers and policy 
makers. Therefore, a numerous studies have been conducted to explore the impact of income structure on banks' risk and performance with contraversely results (Solovjova et al., 2018; Rupeika-Apoga and Saksonova, 2018).

For instance, Boyd et al. (1980), Kwast (1989), Gallo et al. (1996), Rupeika-Apoga et al. (2018) and Rogers and Sinkey (1999), conducted their work and found evidence that non-interest activities relatively reduces risk levels. On the other hand Boyd et al. (1993), Demsetz and Strahan (1997) and Kwan (1998) found evidence that non-interest activities tended to increase risk. More recently, evidence was conducted by DeYoung and Roland (2001) for US commercial banks during the period from 1988 to 1995, were they found that when banks use non-interest activities, they will use less capital, and therefore operational and financial leverage will increase, consequently the riskiness of the bank will increase. Similarly Strioch (2004), and Strioch and Rumble (2006), indicated that non-interest activities increase the volatility of US banks. However, Saunders et al. (2014) found an opposite result for US banks, where non-interest activities decrease banks' risk.

For European banks, Busch and Kick (2009) conducted a study for German banks, were they founded that non-interest activities increases banks' risk. Mercieca et al. (2007) indicated that non-interest activities in small European credit institutions increase their risk during the period from 1997 to 2003. Thus, De Jonghe (2010) and Maudos (2017) indicated the same result for European banks during the period from 1992 to 2007 , and from 2002 to 2012 , respectively.

However, Chiorazzo et al. (2008) conducted a study for 85 banks from Italy during the period from 1993 to 2003 and concluded that non-interest activities improves bank stability. A more comprehensive study was conducted by Demirgüç-Kunt and Huizinga (2010) for 1,334 banks in 101 countries, were they concluded that noninterest activities had a negative impact on banks' risk. However, Sanya and Wolf (2011) examined the impact on non-interest income for 226 banks in 11 emerging markets on banks' risk founded a decrease in banks' risk.

For Asian countries, Hsieh et al. (2013) and Lee et al. (2014) founded a decrease in banks' risk with non-interest income. Also Hidayat et al. (2012) founded a decrease in Indonesians banks' risk. Thus, Lin et al. (2005) concluded that non-interest income decreased Thailand banks' risk. Moreover, Ramasastri et al. (2004) also concluded that Indian banks' risk decreased with non-interest income. On the other hand, Li and Zhang (2013) have found thaat non-interest income increased Chinese banks' risk.

For GCC countries, Ashraf et al. (2016) founded that banks' risk decrease is associated with non-interest income. For Islamic banks, Grassa (2012) analyzed the impact of PLS and non-PLS income on GCC countries banks' performance and risk for the period from 2002 to 2008, were their results indicated that PLS income activities resulted in an increase in banks' risk and insolvency risk. 
Molyneux and Yip (2013) conducted a comparison between the impact of diversification and non-interest (financing) income on the performance and riskiness of Islamic and conventional banks from Malaysia, Saudi Arabia, Kuwait, United Arab Emirates, Bahrain and Qatar, during the period from 1996 to 2009. Their results indicated a better performance and stability on both Islamic and conventional banks associated with non-interest (financing) income. Siti et al. (2018) explored the impact on non-financing income of Indonesian Islamic banks during the period from 2009 to 2013, where they found that non-financing income reduced their risk.

Overall, there is strong empirical literature that supports the importance of nonfinancing income and their effect on banks' performance and risk. However, most of these empirical works so far focused on conventional banks, and Islamic banks have been largely ignored. Therefore, this study tries to fill the gap in the literature by investigating the same issue in GCC countries over the period 2010-2016. The study focused on GCC countries because they are the major players in Islamic banking, where they contribute $68.1 \%$ of the total Islamic assets.

\section{Methodology}

The sample of the study consists of 16 commercial Islamic banks (Islamic Investment banks were excluded from the sample because they conduct their operations differently from Islamic commercial banks) from five countries of GCC Bahrain, Saudi Arabia, Qatar, United Arab Emirates, and Kuwait, where Yemen was excluded from the study due to difficult political conditions they are facing and also Oman was excluded because the Islamic banking sector was only established in 2012 (Table 1);

Table 1. Sample of the Study

\begin{tabular}{|l|l|}
\hline Country & Number of Islamic Banks \\
\hline Bahrain & 4 \\
\hline Kuwait & 1 \\
\hline Qatar & 3 \\
\hline Saudi Arabia & 4 \\
\hline United Arab Emirates & 4 \\
\hline Total & $\mathbf{1 6}$ \\
\hline
\end{tabular}

Sources: The study uses secondary data, where data were drawn from the annual reports of Islamic banks from Bahrain, Saudi Arabia, Qatar, United Arab Emirates, and Kuwait during the period from 2010 to 2016.

The dependent variables used in the panel data analysis consists of risk Z-Score. It is a measure of insolvency risk, and it is used as an indicator of stability and the probability of failure as it was widely used in previous literature (Stiroch, 2004; Sanya and Wolfe, 2011; Stiroh and Rumble, 2006; Nguyen et al., 2012; Grassa, 2012; Molyneux and Yip, 2013; Maudos, 2017) where they indicated that the higher 
this ratio, the lower the insolvency risk and the probability of failure. It is measured by the following formula:

$$
\operatorname{Ln}(Z-S c o r e ~ i t)=\frac{\text { ROAit }+ \text { CARit }}{\sigma \text { ROAit }}
$$

Where: $\mathbf{L n}(Z$-score $)$ is the natural logarith

$\boldsymbol{R O A}$ is the Return on Assets measured as the net income divided by total assets;

$\boldsymbol{C A R}$ is the capital assets ratio, found by dividing the total equity by total asset;

$(\boldsymbol{\sigma R O A})$ is the standard deviation of return of assets (5-years moving windows).

The independent variables used in this study are bank's income structure, Hence, the study focused on non-financing income, therefore, the study used the following variables (DeYoung and Roland, 2001; Stiroch, 2004; Stiroh and Rumble, 2006; Grassa, 2012; Molyneux and Yip, 2013; Lee et al., 2014; Maudos, 2017).

$$
\text { SHnon it }=\frac{\text { Non }- \text { Financing Income it }}{\text { Net Operating Income it }}
$$

Where: SHnon is the share of non-financing income from net operating income;

Non-financing Income is income from sources of Fees and Commission, Trading, and other income;

Net operating Income is the total of financing and non-financing income.

To examine the impact of different types of non-financing income on bank's risk, the following variables are used (Stiroch, 2004; Meslier et al., 2014; Lepetit et al., 2008):

$$
\begin{aligned}
\text { Fees it } & =\frac{\text { Fees and Cpmmission Income it }}{\text { Net } \text { Operating Income it }} \\
\text { Trade it } & =\frac{\text { Trading Income it }}{\text { Net Operating Income it }} \\
\text { Other it } & =\frac{\text { Other Income it }}{\text { Net Operating Income it }}
\end{aligned}
$$

Where: Fees is the share of Fess and Commission income from net operating income;

Trade is the share of trade income from net operating income;

Other is the share of other income from net operating income;

Net operating Income is the total of financing and non-financing income.

Also, the study examined the impact of income diversification on bank's risk, however, it is measured by Hirschmann-Herfindahl Index (HHI), following Stiroch and Rumble (2006), Behr et al. (2007), De Jonghe (2010), and Elas et al. (2010). 
Div it $=1-\left(S H_{N E T}^{2}+S H_{N O N}^{2}\right)$

Bank's risk is affected by other variables than non-financing income. It is affected by several bank characteristics, and therefore, the following control variables were included; Bank Size (Log (total assets) ${ }_{i t}$ ) (Strioh and Rumble, 2006; Laeven and Levine, 2007; Mercieca et al., 2007; Haw et al., 2010; Molyneux and Yip, 2013), Capital Ratio (total equity it / total assets it) (Strioh, 2004; Strioh and Rumble, 2006; Mercieca et al., 2007; Chiorazzo et al., 2008; Sanya and Wolfe, 2011), and Deposit Ratio (total deposit it / total assets it) (Haw et al., 2010) as presented in Table 2:

Table 2. The Study Variables Definitions and Sources

\begin{tabular}{|l|l|l|}
\hline Variables & Proxies & Sources of Data \\
\hline Dependent Variable & Ln(Z-Score $)$ & Annual Report. \\
\hline Z- Score & SHnon & Annual Report. \\
\hline Independent Variables & $\begin{array}{l}|l| \\
\text { Share of non-Financing } \\
\text { Income to net operating } \\
\text { income. }\end{array}$ & Fees \\
\hline $\begin{array}{l}\text { Share of Fees and } \\
\text { Commission to net operating } \\
\text { income. }\end{array}$ & Trade & Annual Report. \\
\hline $\begin{array}{l}\text { Share of Trading Income to } \\
\text { net operating income. }\end{array}$ & Other & Annual Report. \\
\hline $\begin{array}{l}\text { Share of Other Income to net } \\
\text { operating income. }\end{array}$ & Div & Annual Report. \\
\hline Diversification of income. & SIZE & Annual Report. \\
\hline Control Variables. & EQ & Annual Report. \\
\hline Bank Size & DET & Annual Report. \\
\hline Capital Ratio &
\end{tabular}

\subsection{Research Methodology}

To explore the impact of income structure on Islamic banks' risk, the study follows the research by Strioh (2004), Strioh and Rumble (2006), and Molyneux and Yip, (2013) with the following model applied;

$\operatorname{Ln}(\text { Z-Score })_{i t}=\beta_{0}+\beta_{1}$ SHnon $_{i t}+\beta_{2}$ Div $_{i t}+\gamma v_{i t}+\varepsilon_{i t} \ldots \ldots \ldots \ldots \ldots \ldots \ldots \ldots . . . \ldots \ldots$ Model 1)

Where:

Ln(Z-Score $)_{i t}$ is Islamic bank's risk;

SHnon it is Share of non-financing income to net operating income.;

Div ${ }_{i t}$ is Diversification of income.;

$v_{i t}$ is vector of bank control variables including: size, capital ratio, and deposit ratio.; $\mathrm{i}, \mathrm{t}$ are the year and bank respectively;

$\varepsilon_{i t}$ is the error term. 
To better understand the effect of non-financing income on Islamic bank's risk, the study decomposites the non-financing income and the following model is applied, following Strioh (2004), and Strioh and Rumble (2006);

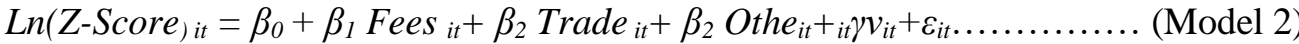

Where:

$\operatorname{Ln}\left(Z-\right.$ Score $\left._{i t}\right)$ is Islamic bank's risk;

Fees ${ }_{i t}$ is Share of Fees and Commission to net operating income;

Trade $_{i t}$ is Share of Trading Income to net operating income;

Othe it is Share of Other Income to net operating income;

$v_{i t}$ is vector of bank control variables including: size, capital ratio, and deposit ratio; $\mathrm{i}, \mathrm{t}$ are the year and bank respectively;

$\varepsilon_{i t}$ is the error term.

\section{Results and Analysis}

Summary statistics on the explanatory variables are reported in Table 3 . The share of financing income of Islamic banks represent, on average $71.5 \%$ of the total Islamic bank' income. On the other hand, the share of non-financing income of Islamic banks represent, on average $28.5 \%$ of total Islamic bank' income.

$\mathrm{Ln}$ (Z-score) is the natural logarithm of Z-score, SHnon is the share of non-financing income to net operating income, SHnet is the share of financing income to net operating income, Fees is the share of fees and commission to net operating income, Trade is the share of trading income to net operating income, Other is the share of other income to net operating income. Div is the diversification of income, EQ is the equity capital / total assets, Size is the ln (Total Assets), and DET is the total deposit / total assets.

Table 3. Descriptive Statistics

\begin{tabular}{|l|l|l|l|l|}
\hline Variables & Mean & SD & Min. & Max. \\
\hline Ln(Z-Score) & 3.2259 & 1.1615 & -0.6404 & 5.9969 \\
\hline SHnon & 0.2859 & 0.1959 & 0.0002 & 1.4860 \\
\hline SHnet & 0.7154 & 0.1974 & -0.4860 & 0.9997 \\
\hline Fees & 0.1421 & 0.0814 & .00010 & 0.3714 \\
\hline Trade & 0.0299 & 0.0318 & -0.0094 & 0.1399 \\
\hline Other & 0.1178 & 0.2034 & -0.1256 & 1.4588 \\
\hline Div & 0.3297 & 0.2112 & -1.4447 & 0.4999 \\
\hline EQ & 0.1588 & 0.0704 & 0.0113 & 0.5838 \\
\hline Size & 7.1557 & 0.6151 & 6.1603 & 9.2636 \\
\hline DET & 0.4706 & 0.3097 & 0.0149 & 0.8321 \\
\hline
\end{tabular}


These results indicated that Islamic banks develop new financial services to compensate for the loss in non-financing income activities, due to competition with their counterparts of conventional banks (DeYoung and Rice, 2004). As it is indicated, the majority of non-financing income is contributed from fees and commission representing $14.1 \%$ of total non-financing income, followed by other sources of non-financing income representing $11.78 \%$ of total non-financing income, and trading sources representing $2.99 \%$ of total non-financing income.

Islamic banks from GCC countries derived a share of their non-financing income from gains from real estate assets and Islamic equities (Molyneux and Yip, 2013). Comparing the structure of income with that of conventional banks from other countries. Islamic banks in GCC countries are almost similar to European banks, were results found that $32.4 \%$ of European bank income is from non-interest income for the period from 2008 to 2012 (Maudos, 2017). On the other hand, Asian countries found that $65.58 \%$ of their income is derived from non-interest income for the period from 1995 to 2009 (Lee et al., 2014). The diversification index is $32.9 \%$, which is relatively low indicating a less diversified income mix. However, risk and insolvency measures are relatively high.

A Variance Inflation Factor (VIF) test was applied to test for multicollinearity; the mean VIF for the explanatory variables was under 5, indicating the absence of multicollenerarity for the two models (Table 4 and 5 present VIF results). The heteroscedasticity test (Brusch-Pagan test) associated with estimation of the models present no heteroscedasticity problem. Thus, accepting the null hypothesis of homoscedasticity. Table 4 reports the results of Value Inflation Factor test to check for multicollinearity in model 1. SHnon is the share of non-financing income to net operating income, Div is the diversification of income, EQ is the equity capital / total assets, Size is the ln (Total Assets), and DET is the total deposit / total assets.

Table 4. VIF Results for Model (1)

\begin{tabular}{|r|r|r|}
\hline Variable & VIF & 1/VIF \\
\hline SHnon & 1.14 & 0.87614 \\
\hline Div & 1.22 & 0.821541 \\
\hline Size & 1.33 & 0.749521 \\
\hline DET & 1.28 & 0.779252 \\
\hline Mean VIF & 1.27 & 0.789661 \\
\hline
\end{tabular}

Table 5 reports the results of Value Inflation Factor (VIF) test was applied to check for multicollinearity. Fees is the share of fees and commission to net operating income, Trade is the share of trading income to net operating income, Other is the share of other income to net operating income, Div is the diversification of income, EQ is the equity capital / total assets, Size is the ln (Total Assets), and DET is the total deposit / total assets. 
The Effect of Financing and Non-Financing Income on Islamic Banks' Risk: Evidence from Gulf Cooperation Council Countries

188

Table 5. VIF Results for Model (2)

\begin{tabular}{|r|r|r|}
\hline Variable & VIF & $\mathbf{1 / V I F}$ \\
\hline Fees & 2.49 & 0.40192 \\
\hline Trade & 1.85 & 0.540758 \\
\hline Other & 1.29 & 0.778134 \\
\hline EQ & 1.13 & 0.882442 \\
\hline Size & 1.31 & 0.766169 \\
\hline DET & 1.51 & 0.66331 \\
\hline Mean VIF & 1.59 & \\
\hline
\end{tabular}

The Lagrange Multiplier (LM) test was applied and the results indicated the use of panel data analysis. Thus, Hausman test was applied were the results indicated that fixed-effect model was more appropriate than random-effect model.

Table 6, provides fixed panel estimation results on the impact of non-financing income and diversification on Islamic banks' risk measured by $\mathrm{Ln}(\mathrm{Z}$-score). The results indicated a positive and significant relationship between non-financing income and Islamic bank's risk at 10 percent confidence level. However, there is no significant relationship between diversification index and Islamic bank's risk indicating that non-financing income decreases Islamic bank's risk and improve bank's stability in GCC countries.

These results are consistent with those of Gallo et al. (1996), Rogers and Sinkey (1999), Molyneux and Yip (2013), Ashraf et al. (2016), and Siti et al. (2018), where they found that banks that relay on non-financing income, will assume less risk. On the other hand, it is inconsistent with the results of DeYoung and Roland (2001), Strioh (2004), Strioh and Rumble (2006), and Maudos (2017), where they found that banks that relay on non-financing income will assume to be more risky.

Furthermore, for control variables deposit ratio was the only factor that indicated a positive and significant relationship with Islamic bank's risk. This indicated that financing sources increase Islamic bank's risk because they will be affected by market interest rates fluctuations. Thus, this result is consistent with the results of Kwanye and Eisenbeis (1997), and Chiorazzo et al. (2008).

Table 6. Risk and Diversification

\begin{tabular}{|c|c|}
\hline Variable & Fixed Panel \\
\hline Constant & $1.9798(0.282)$ \\
\hline SHnon & $0.0158(0.07)^{* * *}$ \\
\hline Div & $0.0014(0.791)$ \\
\hline $\boldsymbol{E Q}$ & $-0.0067(0.764)$ \\
\hline Size & $-0.0616(0.789)$ \\
\hline DET & $0.0275(0.019)^{* *}$ \\
\hline Number & 112 \\
\hline $\boldsymbol{R}^{2}$ & 0.123 \\
\hline
\end{tabular}


Table 6 presents the results of the effect of non-financing income and diversification on Islamic banks' risk measured by $\mathrm{Ln}$ (Z-score) using fixed panel estimation, where SHnon is the share of non-financing income to net operating income, Div is the diversification of income, EQ is the equity capital / total assets, Size is the ln (Total Assets), and DET is the total deposit / total assets. P-values are reported in parentheses. All t-statistics are based on robust standard errors. ***;**** represent significance at the $1 \%, 5 \%$ and $10 \%$ level, respectively.

Looking deeper by dividing non-financing income into its main components (fees and commission income, trading income, and other income) Table 7 provides fixed panel estimation results. The results indicated a positive and significant relationship between trading income, and other income and Islamic bank's risk at 10 percent confidence level. However, there is no significant relationship between fees and commission income, and Islamic bank's risk. These results also indicate that nonfinancing income components decreases Islamic bank's risk and improve bank's stability in GCC countries, where the coefficient results indicated that bank's risk is affected and decreased more by trade income, and secondly by other income, and fess and commission income does not matter. Furthermore, for control variables deposit ratio also was the only factor that indicated a positive and significant relationship with Islamic bank's risk. This indicates that financing sources increase Islamic bank's risk because they will be affected by market interest rates fluctuations. Therefore, there are more volatile.

Table 7. Risk and non-financing income composition

\begin{tabular}{|c|c|}
\hline Variable & Fixed Panel \\
\hline Constant & $7.9846(0.000) *$ \\
\hline Fees & $0.0360(1.49)$ \\
\hline Trade & $0.2064(0.003) * *$ \\
\hline Other & $0.0134(0.048) * *$ \\
\hline EQ & $-0.0048(0.823)$ \\
\hline Size & $-0.3945(0.108)$ \\
\hline DET & $0.0309(0.006) * * *$ \\
\hline Number & 112 \\
\hline $\boldsymbol{R}^{\mathbf{2}}$ & 0.2107 \\
\hline
\end{tabular}

Table 7 presents the results of the effect of the components of non-financing income on Islamic banks' risk measured by Ln(Z-score), using fixed panel estimation, Fees is the share of fees and commission to net operating income, Trade is the share of trading income to net operating income, Other is the share of other income to net operating income, Div is the diversification of income, EQ is the equity capital / total assets, Size is the ln (Total Assets), and DET is the total deposit / total assets. $P$ values are reported in parentheses. All t-statistics are based on robust standard errors. $* * * * * * *$ represent significance at the $1 \%, 5 \%$ and $10 \%$ level, respectively. 


\section{Conclusions and Recommindations}

This study analyzes the impact of non-financing income on Islamic bank's risk in the GCC banking sector for the period between 2010 and 2016. Using fixed panel analysis, the study found evidence that non-financing income decreases Islamic bank's risk and improves its stability. More specifically, when dividing nonfinancing income into its main components, the study found that trading income contributes the most effect, followed by other income, while fess and commission income does not have any effect.

Therefore, the study recommended Islamic banks' to increase the share of nonfinancing income by proliferation of new products, and open new channels of revenue to protect against the volatility in market interest rate and to face the competition by their counter parts of conventional banks and other financialinstitutions. These findings have important implications to Islamic banks in order to deal with non-financing income and to boost their growth in the worldwide. Moreover, these findings have important implications for Islamic banks' manager and policy makers, researchers and academicians, meanwhile the study recommended future research in this area by including other variables and other countries.

\section{References:}

Behr, A., Kamp, A., Memmel, C., Pfingsten, A. 2007. Diversification and the Banks' Riskreturn Characteristics - Evidence from Loan Portfolios of German Banks. Deutsche Bundes bank Discussion Paper Series 2. Banking and Financial Studies, 05/2007.

Boyd, J.H., Hanweck, G.A., Pithyachariyakul, P. 1980. Bank Holding Company Diversification. Proceedings from a Conference on Bank Structure and Competition.

Boyd, J.H., Stanley, L.G., Shawn, H.R. 1993. Bank holding company mergers with nonbank financial firms: Effects on the risk of failure. Journal of Banking and Finance, 17, 43-63.

Busch, R., Kick, T. 2009. Income Diversification in the German Banking Industry. Bunds Bank Discussion Paper, 09/2009.

Chiorazzo, V., Milani, C., Salvini, F. 2008. Income Diversification and Bank Performance: Evidence from Italian Banks. Journal of Financial Services Research, 33, 181-203.

Dawood, A., Ramady, Moh., Albinali, K. 2016. Financial fragility of banks, ownership structure and income diversification: Empirical evidence from the GCC region. Research in International Business and Finance, 38, 56-68.

Demirgüc-Kunt, A., Huizinga, H. 2010. Bank Activity and Funding Strategies: The Impact on Risk and Returns. Journal of Financial Economics, 98, 626-650.

Demsetz, R., Strahan, P.E. 1997. Diversification, Size and Risk at Bank Holding Companies. Journal of Money, Credit and Banking, 29, 300-313.

De Jonghe, O. 2010. Back to the Basics in Banking? A Micro-Analysis of Banking System Stability. Journal of Financial Intermediation, 19, 387-417.

DeYoung, R., Karin P.R. 2001. Product Mix and Earnings Volatility at Commercial Banks: Evidence from a Degree of Total Leverage Model. Journal of Financial Intermediation, 10, 54-84. 
DeYoung, R., Tara, R. 2004. Non-interest Income and Financial Performance at U.S. Commercial Banks. The Financial Review, 39, 101-127.

EY. 2016. World Islamic Banking Competitiveness Report 2016.

Gallo, J.G., Apilado, V.P., Kolari, J.W. 1996. Commercial Bank Mutual Fund Activities: Implications for Bank Risk and Profitability. Journal of Banking and Finance, 20, 1775-1791.

Grassa, G. 2012. Islamic Banks' Income Structure and Risk: Evidence from GCC Countries. Accounting Research Journal, 25(3), 227-241.

Haw, I.M., Ho, S.S.M., Hu, B., Wu, D. 2010. Concentrated Control, Institutions, and Banking Sector: An International Study. Journal of Banking and Finance, 34, 485497.

Hidayat, Wahyu, Y., Makoto, K., Hiroaki, M. 2012. Bank Risk and Non-Interest Income Activities in the Indonesian Banking Industry. Journal of Asian Economics, 23, 335343.

Hsieh, Meng-Fen, Pei-Fen Chen, Chien-Chiang Lee, Shih-Jui Yang. 2013. How Does Diversification Impact Bank Stability? The Role of Globalization, Regulations, and Governance Environments. Asia-Pacific Journal of Financial Studies, 42, 813-844.

Kwast, M. 1989. The Impact of Underwriting and Dealing on Bank Returns and Risk. Journal of Banking and Finance, 13, 101-125.

Kwan, S., Eisenbeis, R. 1997. Bank Risk, Capitalization, and Operating Efficiency. Journal of Financial Services Research, 12(2/3), 117-131.

Kwan, S.H. 1998. Securities Activities by Commercial Banking Firms' Section 20 Subsidiaries: Risk, Return and Diversification Benefits. Federal Reserve Bank of San Francisco, Working Paper, 98-10.

Laeven, L., Levine, R. 2007. Is there a Diversification Discount in Financial Conglomerates? Journal of Financial Economics, 85, 331-367.

Lee Chien-Chiang, Yang Shih-Jui, Chang Chi-Hung. 2014. Non-Interest Income, Profitability, and Risk in Banking Industry: A Cross-Country Analysis. North American Journal of Economics and Finance, 27, 48-67.

Lepetit, L., Nys, E., Rous, P., Tarazi, A. 2008. Bank Income Structure and Risk: An Empirical Analysis of European Banks. Journal of Banking and Finance, 32, 14521467.

Li, Li., Yu, Z. 2013. Are there Diversification Benefits of Increasing Non-Interest Income in the Chinese Banking Industry? Journal of Empirical Finance, 24, 151-165.

Lin, S.L., Wu, S., Penm, J.H.W., Terrell, R.D. 2005. The Relationship and Causality Testing between Diversification, Risk and Financial Performance: Empirical Examination in Taiwan's Banking Industry. International Journal of Services Technology and Management, 6, 556-575.

Maudos, J. 2017. Income Structure, Profitability and Risk in the European Banking Sector: The impact of the crisis. Research in International Business and Finance, 39, 85101.

Mercieca, S., Klaus, S., Wolfe, S. 2007. Small European Banks: Benefits from Diversification? Journal of Banking and Finance, 31, 1975-1998.

Meslier, C., Tacneng, R., Tarazi, A. 2014. Is Bank Income Diversification Beneficial? Evidence from an Emerging Economy. Journal of International Financial Markets, Institutions and Money, 31, 97-126.

Molyneux, P., Yip, J. 2013. Income Divarication and Performance of Islamic Banks. Journal of Financial Management Markets and Institutions, Società Editrice il Mulino, 1(1), 47-66. 
Nguyen, M., Skully, M., Perera, S. 2012. Market Power, Revenue Diversification and Bank Stability: Evidence from Selected South Asian Countries. Journal of International Financial Markets, Institutions and Money, 22, 897-912.

Ralf, E., Hackethal, A., Holzhäuser, M. 2010. The Anatomy of Bank Diversification. Journal of Banking and Finance, 34, 1274-1287.

Ramasastri, A.S., Samuel, A., Gangadaran, S. 2004. Income Stability of Scheduled Commercial Banks: Interest Vis-à-Vis Non-interest Income. Economic and Political Weekly, 39, 1311-1316.

Rogers, K., Sinkey Jr, J.F. 1999. An analysis of Non-Traditional Activities at U.S. Commercial Banks. Review of Financial Economics, 8, 25-39.

Rose, P.S., Hudgins, S.C. 2013. Bank Management and Financial Services (9th ed.). McGraw-Hill /Irwin Publishing.

Roy, D.A. 1991. Islamic Banking. Middle Eastern Studies, 27, 427-456.

Rupeika-Apoga, R., Saksonova, S. 2018. SMEs' Alternative Financing: The Case of Latvia. European Research Studies Journal, 21(3), 43-52, DOI: 10.35808/ersj/1042.

Rupeika-Apoga, R., Zaidi, H.S., Thalassinos, E.Y., Thalassinos, I.E. 2018. Bank Stability: The Case of Nordic and Non-Nordic Banks in Latvia. International Journal of Economics and Business Administration, 6(2), 39-55.

Sanya, S., Wolfe, S. 2011. Can Banks in Emerging Economies Benefit from Revenue Diversification? Journal of Financial Services Research, 40, 79-101.

Saunders, A., Schmid, M.M., Walter, I. 2014. Non-Interest Income and Bank Performance: Is Banks' Increased Reliance on Non-Interest Income Bad? SSRN Electronic Journal.

Siti, S., Mat, I., Masturah, M., Hanif, A. 2018. Islamic Banks' Fee Income, Characteristics and Risk: Panel Analysis Evidence from Indonesia. Journal of Emerging Economies and Islamic Research, 6(1), 6-16.

Solovjova, I., Rupeika-Apoga, R., Romanova, I. 2018. Competitiveness Enhancement of International Financial Centres. European Research Studies Journal, 21(1), 5-17, DOI: $10.35808 / \mathrm{ersj} / 925$.

Stiroh, K.J. 2004. Diversification in Banking: Is non-Interest Income the Answer? Journal of Money, Credit and Banking, 36, 853-882.

Stiroh, K.J., Rumble, A. 2006. The Dark Side of Diversification: The case of US Financial Holding Companies. Journal of Banking and Finance, 30, 2131-2161. 